\title{
The war of the future as a strategic guideline for the forming the critical technologies list
}

\section{Artem Kupchyn ${ }^{\mathrm{A}}$; Viktor Dykhanovskyi ${ }^{\mathrm{B}}$; Yevhen Kolotukhin ${ }^{\mathrm{C}}$}

Received: January 21, 2020 | Revised: February 28, 2020 | Accepted: February 29, 2020

DOI: $10.33445 /$ sds.2020.10.1.2

\begin{abstract}
Predicting scientific and technological development and, as a result, developing a list of critical technologies in advanced countries is quite common and systematic.

Ukraine, however, forms such a list exclusively for the defense sphere. Highlighting the most promising technological directions that can be implemented in the field of weapons and military equipment requires a clear understanding of the key principles for the operation of new and advanced weapons, as well as the relevance and priority of the development of certain civilian technological areas, which may eventually move into the military.

This paper provides a forecast of the development of the security situation in the world as of 2045. It identifies likely leaders who will spend more than twice as much on their defense, with only two advanced countries that are likely to be at the highest level of military power. It also noted a possible decline in Russia's military capabilities, but an armed threat remains.

The origin of a new sphere of military presence is described - cyberspace, which necessarily entails a change in the forms of future wars. It is also noted that the rapid development of certain technologies, which is currently undergoing scientific and technological development, can lead to catastrophic consequences for all humanity.

Some of the achievements and main principles of the Fifth and Sixth Technological Units, which will inevitably be applied in the development of the latest weapons, are outlined.

Possible directions of modernization of certain available types of weapons are described, as well as key indications of future military conflicts and prospective weapons. In addition, the article provides some data that is drawn from science fiction, but it is quite likely to be used in the creation of promising weapons complexes based on the latest physical principles of action.
\end{abstract}

Keywords: war of the future, prospective weapons, newest technologies.

\section{Introduction}

Highlighting the narrowest, most promising and strategically important scientific and technological directions for the state, most countries create preconditions for the growth of national economies and the development of the defense-industrial complex in particular. The governments of most countries concentrate their efforts on the development of the most important, key scientific areas and technologies critical technologies (CT) [1].
The main tools for CT detection are forwardlooking research in the scientific and technological field, more commonly known as the technology foresight in foreign practice. Ukraine, since 2017, has also joined such world practice.

When making strategic decisions on the development of a defense-industrial complex, it is necessary to understand the requirements for promising weapons, which must be made in the future. Conducting a technological foresight to

\footnotetext{
A Central Research Institute of Armaments and Military Equipment of the Armed Forces of Ukraine, PhD student. 28, Vozduhoflotsky, ave, Kyiv, 03049, Ukraine. e-mail: kupchyn.artem@ukr.net. ORCID: 0000-0003-2013-691X

B Central Research Institute of Armaments and Military Equipment of the Armed Forces of Ukraine, Leading Researcher, Dr of Technical Sciences. 28, Vozduhoflotsky, ave, Kyiv, 03049, Ukraine. e-mail: 044873@ukr.net. ORCID: 0000-0002-1600-3973

c Central Research Institute of Armaments and Military Equipment of the Armed Forces of Ukraine, Senior Researcher. 28, Vozduhoflotsky, ave, Kyiv, 03049, Ukraine. e-mail: evgenkolot81@gmail.com. ORCID: 0000-0002-9500-1932
} 
develop a list of promising critical technologies in the defense field in most countries is based on an expert survey of the most qualified specialists. This allows obtaining an objective list of CTs, the development and implementation of which is the basis for the creation of the latest models of weapons and military equipment (WME).

However, even before the survey began, the experts were faced with a serious question about the feasibility of using certain technologies in the future. If we talk about the prospect of creating new weapons for the period of $15-20$ years, it is already necessary today to at least approximately understand the nature and forms of warfare of the future, the principles of building new military platforms and the likelihood of using promising technologies in them. That is, at the present stage, the experts should imagine what the war of the future would be like when formulating a list of critical technologies in the defense sphere.

The world's most advanced nations systematically make such predictions, forming an understanding of future armed conflicts, and make strategic decisions accordingly.

\section{Analysis of recent research and publications.}

Unfortunately, in Ukraine it is now quite difficult to find scientific publications on forecasting the development of new weapons and their forms of use. This article compiles the most readily available materials on forwardlooking weapons, as well as some science fiction data that may also be a reality in the near future.

The proposed work has the character of an analytical article, where the authors analyzed more than 700 scientific publications of the most recognized research organizations of the world, such as RAND (USA), SIPRI (Sweden), Global Research (Canada), as well as the work of scientists of the Ministry of Defense of Great Britain and military researchers of Ukraine. The high concentration of publications on the origin and development of the latest technologies among reputable international research organizations indicates a significant interest of developed countries in issues of a similar nature.

The result of the analysis of recent research and publications is outlined in the main body of the article.

\section{Material and Method}

The purpose of this work is to identify the latest developments in the field of WME, identify key characteristics of advanced weapons, as well as outline new trends in military use and future wars.

\section{Results and discussion}

\section{The overall picture of the security situation in 2045}

"Global Strategic Trends - Out to 2045" is a large-scale strategic study of global security trends conducted by the UK Department of Defense, which predicts the most likely scenario for the deployment of security forces in the world.

Thus, by 2045, the world's largest economies are likely to be China and the US, and India will become the only country at the second economic level. As economies grow, defense spending will increase. The US and China are projected to spend half of their global defense spending by 2045 on their defense. India's defense budget will come second [2].

Russia will not be able to afford to meet the defense spending of the leaders, though its Armed
Forces will also have increased funding. NATO member countries defense spending will increase substantially. However, both Russia and the European member states will have defense spending that will only occupy the third place.

Unlike civil technologies, which become cheaper over time, military technologies do not have this tendency. Recent military platforms are more expensive than their predecessors, so it can be assumed that by 2045 only the US and China will be able to create advanced air forces and fleets [2]. Interestingly enough, in 2045 Russia will probably no longer act as a significant military threat to the United States. China enters the international arena confidently and boldly, which will not concede to the United States in 2045. 


\section{Key features of future weapons and future military conflicts}

By 2045, the use of unmanned vehicles will be quite common, which will probably lead to physical confrontation between them. Future military conflicts are predicted to be bloodless. In addition, without physical destruction, the enemy will be harmed by influencing electrical and information networks, banking, economic and social systems, etc. Even in the case of violence, technology will make its use more accurate and effective. For example, targeted killings of the ruling elite will have far greater effects than war. Targeting accuracy will be improved, in particular by using electronic gadgets. Targeting weapons on human DNA will no longer be fantastic. We can also see a complex environmental war that can spread diseases of plants and humans to insects or hybrids. Crops and livestock can be destroyed and people incapacitated or killed. Globalization, the diffusion of technology and information is likely to give society access to sophisticated technological opportunities. This is likely to increase the number of terrorist attacks [2].

The latest military technologies will necessarily include artificial intelligence, robotics, system autonomy, 3D printing, nanotechnology, biotechnology, quantum computing [3]. Today in the advanced countries of the world there are already designed promising samples of WME, which introduce technologies such as artificial intelligence [4], smart textiles [5], augmented reality [6], robotic complexes and unmanned aerial complexes [7].

An important feature of future weapons will be a fairly functional interoperability of man and machine. In addition, a new form of armed struggle is emerging - the "conscience war", which are aimed not at conquering territories but at capturing people's consciousness [8].

RAND researchers have identified four global threats to human security, two of which could be implemented in the military. These are the additive manufacturing technologies and Artificial Intelligence (Al).

Additive manufacturing and 3-D printers can be home appliances by 2040 . Private firms are already experimenting with printed footwear, food and firearms. The product can be manufactured locally and by anyone. According to the research team, three-dimensional printing can be devastating to the economy and society. The next wave of additive technology capabilities will focus on materials that can be modified. The United States understands that gaining significant benefits in this technology will provide a dual strategic advantage in both the economic and military fields. 3D printing for military platforms is a perspective that will affect the logistics system [9]. It is possible to produce details of every single military unit, including on the battlefield.

An evil joke for humanity may be the introduction of artificial intelligence. Machines that can learn, think and act can probably become our common enemy [10].

The introduction of Al will allow you to forget about periodic updates of the system, since Al will constantly improve itself, and also "gaps in the skills" of specialists are completely eliminated. The corruption component and any other human factor is nullified. Artificial intelligence can be used both in the domestic sphere and in the military, both in training and in combat. For example, simulating unpredictable and adaptive adversaries to train fighter pilots; solving logistical problems; automation of combat operations in unmanned operations; development of new weapons; identifying goals and more. The use of $\mathrm{Al}$ in the military sphere is no longer in doubt [4].

Artificial intelligence is already being introduced for the development of unmanned marine vehicles [11].

However, in case of software damage (possibly from the intervention of opponents) the consequences can be fatal. Like RAND and Swedish researchers, everyone is of the opinion that Al will become one of the greatest threats to humanity in 2040, and nuclear stability is a particular concern [12].

Future weapons systems will be allowed to retrieve targets and decide on their own destruction, but a human control element is still needed. Such issues have increasingly begun to be raised when discussing development prospects at UN meetings [13].

In 2017, the UK Department of Defense developed the Concept for the Transition to the Use of Autonomous Maneuver Battalion Groups 
by 2035 . According to it, the battalion tactical group will consist of up to 350 people, which will have 50 vehicles and 80 robotic autonomous systems (mainly 2 unmanned platforms (ground and UAV) per transport unit). According to the concept, some of the available UAV's should provide, in addition to visual, acoustic reconnaissance on the battlefield, and groundbased robotic systems equipped with weapons are designed to replace human resources as much as possible during combat operations. Such a strike group must be capable of conducting autonomous combat operations within 7 days in isolation from the main forces at distances up to $1600 \mathrm{~km}$.

The sensor system of the battalion group at distances up to $15 \mathrm{~km}$ should be able to detect and assure targets, and at a range of up to $30 \mathrm{~km}$ - to constantly monitor the terrain to understand the situation on the battlefield [14].

It is interesting that the American agency DARPA is quite productive in the development of biomedical and network-centric warfare technologies.

According to the Horizon 2020 European Innovation Development Program, priority areas have identified information and communication technologies, nanotechnologies, advanced materials and biotechnologies [15].

The NATO Organization for Science and Technology (STO) in 2018 reported on the financing of key activities (the first three priority areas are outlined) [16]:

1. Analysis of information (decision making, processing of large volumes of data, multi-domain situational awareness, etc.);

2. Extended system concepts (human-machine complexes, clusters and swarms, modular systems, integration of reality and simulations);

3. Improving human productivity and health (human resilience, health optimization, improved cognitive performance, human-machine interfaces).

\section{Prospects for the development of certain types of weapons \\ HELICOPTERS}

Artificial intelligence and augmented reality technologies will have a significant impact on the helicopter's combat capabilities. Particularly important will be the modularity of the design, cyber defense and hybrid engine technologies. Among the group of priority technological directions are weapons of directional energy, integration on board helicopters of the UAV control system for operation in the composition of pilot-unmanned groups, multifunctional distributed aperture of radio engineering systems.

Promising helicopter technologies are: "Future Rotorcraft Technologies" (rotary machine technology); "Fly-by-Light" (control of aircraft based on fiber-optic command transmission); the use of "smart" electrohydraulic actuators; Smart Material technologies; Tilt Rotor [17].

\section{ARMOR ARMAMENTS}

The rapid development of robotics has already been reflected in the latest developments in WME. The combat vehicle will only be optional manned by a man, in the near future on pilotunmanned platforms with the widespread introduction of augmented reality technology and artificial intelligence. The transition from diesel engine to fully electric combat vehicles will be mandatory [18].

\section{NUCLEAR WEAPONS}

In 2018, there has been a significant improvement in the world's nuclear security. North Korea has pledged to abandon nuclear weapons, a ballistic missile program and has pledged to work on "full denuclearization" of the Korean peninsula. Iran, amid US sanctions, continues to implement a comprehensive plan of action to curb its nuclear activities. Minor disputes between the US and Russia over the development of recent missiles with a restricted range at the end of the year subsided.

In such circumstances, it is hoped that nuclear weapons will not be used in future conflicts. There is no information on the latest developments in this field [19].

\section{CHEMICAL AND BIOLOGICAL WEAPON}

The most well-known cases of chemical and biological weapons use are the military conflict in Syria and the attempt to kill the Skrypals in the UK in 2018. Such cases are isolated and not systematic in nature, and there is no global tendency for the development of chemical and biological weapons.

In [20] experts have determined that chemical weapons used in Syria have shown rather limited 
military benefits, so the likelihood of their use in the future is quite low.

Swedish researchers say that the use of biological weapons has not been detected at all in the last year [21].

\section{MILITARY EQUIPMENT OF SOLDIERS}

The soldier of the future is an equipped combat vehicle, with a man inside. First of all, it is an exoskeleton with bionic knee generators, flexible ballistic plates for body protection, and an integrated assault rifle. The augmented reality system will allow you to quickly and qualitatively identify combatants (friend-foe) and make decisions based on an online battle map. The newest headset systems will have sound protection, a versatile interface of weapons and main systems. New types of camouflage are also being developed, including e-textiles, smarttextiles and multispectral camouflage [22].

\section{HYPERSONIC ROCKETS}

The undisputed trend of the next generation of weapons has become hypersonic weapons. The flight speed of such a rocket is at least several times the speed of sound. It is able to dodge and hide its exact targets just seconds before the impact. In addition, such weapons are capable of destroying targets without any explosives using only their kinetic energy. The US, Russia and China are leading the race in the development of hypersonic rockets. Within ten years, hypersonic rockets are likely to be deployed and potentially offered on the international market.

Hypersonic technology is extremely difficult to master. Ignition of a hypersonic cruise missile engine can be compared to ignition of a match at a wind speed of 2000 miles per hour (approximately $900 \mathrm{~m} / \mathrm{s}$ ). Moreover, the shape of the rocket changes under the rigidity of hypersonic flight, creating great challenges for flight control.

Despite all the difficulties of such technologies, Japan and Europe have expressed a desire to develop even hypersonic airliners [23].

\section{ROBOTICS}

The use of robotic military equipment in advanced countries today is not surprising. Autonomous weapons systems will soon make their own decisions, and soldiers will co-exist and cooperate with the work. There is a gradual merger of man and machine (cobotic technologies). At some point, machines will be able to reproduce and reprogram themselves. Perhaps at some stage we will have to talk about the evolution of the first postbiological life forms on the planet.

The US agency DARPA plans to improve the performance of soldiers through molecular and neurobiology (implantation of body parts).

However, the agency also invests in advanced robotics, machine learning, artificial intelligence, and more [24].

\section{XENOBOTS}

Scientists at the American University of Vermont have announced the creation of the world's first living robots. They were created from stem cells of African frogs of the species Xenopuslaevis and programmed using an evolutionary computer algorithm. The size of these "living" creatures is less than one millimeter. The special feature of stem cells is that they can develop into cells of any type, so these microrobots can heal and self-repair.

Xenobot is a biological machine small enough to move inside human bodies. At present, scientists have only been able to make the "new life" move. This was achieved by the fact that xenobots are collected from the cells of the skin and heart of the embryo. The first - passive and serve as a kind of outer shell or frame. At the same time, the cells of the heart muscle contract and activate xenobot. The movement of the body is programmed by a computer. In essence, it is a new class of beings - living programmable organisms [25].

It is likely that such scientific advances can be used in the military field. The movement of a programmed microorganism in the human body creates new challenges and threats.

\section{CYBERNETIC WAR}

History shows us an interesting example, as soon as a person begins to learn a new sphere of life, wars begin there. At first it was just land, then the sea, and later air and even space. But man also created for himself an artificial sphere of life activity - cyberspace. In 2016, NATO formally identified cyberspace as a new operational warfare zone [26]. 
Cyberwar is the manipulation of data in information networks to change the functioning of economic, political, social systems, etc. [27].

There is even a growing threat of virtual social warfare.

Leading RAND scientists believe that the greatest threat of cyber warfare exists from Russia, China, the DPRK and Iran.

A clearly known fact of Russian cyber operations is the examples in Ukraine and Montenegro, where the purpose was to create destabilizing moods in the society by posting fake news on the Internet. Chinese cyber operations are mainly aimed at espionage [28].

NETWORK-CENTRIC wars, as a new emerging character of combat management, is still available to only a few of the most developed countries. The basic principle is to integrate all sources of information into a single network and to bring a complete picture of the fighting to all participants in the war. All possible sources of information, from the indentured soldier's camera to the individual radar reconnaissance system, are combined into a single network.

It is essentially an online combat map that contains all the information on combat, technical, logistics and medical support, the position of troops and routes, the resources remaining and the ability to complete them as quickly as possible. The availability of real-time information allows commanders to make smart and quick decisions, which is the key to quality combat performance.

\section{GENOMODIFIED ORGANISMS}

In 2018, the shocking news came that a team of Chinese scientists was able to edit the DNA of a human embryo. Professor He Jianqui stated that he had successfully modified two embryos made from the sperm of an HIV-positive donor and implanted to a healthy mother, who then gave birth to healthy twin girls. In fact, the professor created the world's first humans with a modified genome [29].

If the alteration of the human genome is quite unusual, then the editing of genomes of other terrestrial creatures has become widespread. For example, Oxitec, a British company, has released 450,000 genetically modified mosquitoes in the Baja region of Brazil for malaria and other diseases [30].
Genetically modified organisms can be used not only for peaceful purposes. It is likely that such weapons can cause significant harm to both the individual and the agricultural sector of the country as a whole. This, in turn, can affect both the health of the population and the economic situation of a particular region or state as a whole.

\section{FIGHTING INSECTS}

DARPA is conducting experiments with drones that are comparable to insects. A set of such plastic insects programmed to co-operate as a swarm operate without further human instruction. Drones collaboration can take many forms, from hierarchical collaboration to a more decentralized approach called "quick coordination". Consensus in decision-making is established on the basis of the colony of ants without an established leadership structure. DARPA examines deep neural networks to improve the ability to recognize targets.

A similar example is the Israeli drone Harpy, which can independently search and destroy targets without human intervention [31].

Unfortunately, it is difficult to find scholarly publications on this subject, but there is a great deal of online content for futuristic focuses where science fiction writers describe swarms of fighting insects as a weapon of the future. Thousands of insects, united in a single swarm, can quickly wipe out any type of weapon or manpower, with little material damage.

\section{SMART DUST}

Another rather interesting futuristic direction for the likely weapon of the future is smart dust. It is a collection of tiny devices that are integrated into a single system using a wireless signal. Millions of motes can create artificial natural disasters or just visual and radio noise. There are no known facts about the creation of such devices, however, as practice shows - if it is written and filmed by sci-fi, then it is worth waiting for in the future.

\section{HAARP}

The High Frequency Active Auroral Research Program is a little-known but critically important US military defense program aimed at modifying weather by electromagnetic radiation. In this way, you can create any natural cataclysm, such as earthquakes, tsunamis, disruption of 
communication systems, etc. This technology was created and has been active since the mid-1990s. Officially, HAARP was shut down in 2014 as a weapon of mass destruction capable of destabilizing environmental systems worldwide. However, it is uncertain that under certain conditions such a program can be resumed [32].

\section{Conclusions}

Thus, conducted analysis showed that information technology, the creation of cuttingedge materials and biotechnology are developing quite widely around the world. In this case, the technologies of 3D printing and artificial intelligence, mentioned above, are gradually relegated to the background, indicating that there are ready enough serious developments in these areas or the loss of interest in them, which is unlikely.

In the 21st century, a new plane for warfare has emerged - cyberspace. Cyber warfare has become a serious threat to society, as has the emergence of artificial intelligence and additive manufacturing.

By 2045 , only two countries (the US and China) are projected to have the most developed Armed Forces, and Russia will no longer pose a threat to the US.

The future generation of weapons will be based on the principle of human and machine interoperability, using artificial intelligence, augmented reality, robotics, nano and biotechnologies.

Future military conflicts are predicted to be bloodless. Physical confrontation will take place between unmanned military platforms.

There is a high probability of using quite unusual military developments such as combat insects, smart dust, GMOs and more.

The analysis of future weapons presented in this paper can serve as a benchmark for the expert formation of a list of critical technologies in the defense sphere of Ukraine.

\section{References}

1. Kupchyn A., Sotnyk V. (2019). Krytychni tekhnolohiyi $v$ oboronniy sferi. Novyy pohlyad. [Critical technologies in the defense sphere. A new look]. Weapons and military equipment, № 2, pp. 35-42 [in Ukrainian]. https://doi.org/10.34169/2414-

0651.2019.2(22).35-41

2. Strategic Trends Programme. Global Strategic Trends - Out to 2045. Shrivenham, Swindon: Strategic Trends Programme. Development, Concepts and Doctrine Centre. 2017, 172 p.

3. Sibylle Bauer, Vincent Boulanin, Noel Kelly, Moa Peldán Carlsson. Emerging military and security technologies. SIPRI. URL: https://www.sipri.org/research/armamentand-disarmament/emerging-military-andsecurity-technologies.

4. Slyusar V. (2019). Shtuchnyy intelekt yak osnova perspektyvnykh merezh upravlinnya. [Artificial Intelligence as a Basis for Advanced Management Networks]. Abstracts of reports of the international scientific-practical conference "Problems of coordination of military-technical and defense-industrial policy in Ukraine. Prospects for the development of weapons and military equipment", № 7, pp. 89-90 [in Ukrainian]. https://doi.org/10.13140/RG.2.2.30247.500 87

5. Novak D.S., Plavan V.P. (2019). Rozrobka smart tekstylyu dlya pidvyshchennya komfortnosti rechovoho mayna viys'kovosluzhbovtsiv [Development of smart textiles to increase the comfort of real property of military personnel]. Abstracts of reports of the international scientificpractical conference "Problems of coordination of military-technical and defense-industrial policy in Ukraine. Prospects for the development of weapons and military equipment", № 7, pp. 208-210 [in Ukrainian].

6. Dovhopolyy A.S., Senatorov V.M., Huslyakov O.M., Hrechukhin M.E. (2019). Vprovadzhennya tekhnolohiy dopovnenoyi real'nosti u viys'kovu tekhniku v Ukrayini 
[Implementation of augmented reality technologies in military equipment in Ukraine]. Abstracts of reports of the international scientific-practical conference "Problems of coordination of militarytechnical and defense-industrial policy in Ukraine. Prospects for the development of weapons and military equipment", № 7, pp. 159-160 [in Ukrainian].

7. Dovhopolyy A.S., Huslyakov O.M. (2019). Kontseptual'ni osnovy osnashchennya pidrozdiliv Zbroynykh Syl Ukrayiny vitchyznyanymy nazemnymy robotyzovanymy kompleksamy [Conceptual bases of equipping of units of the Armed Forces of Ukraine with domestic terrestrial robotic complexes]. Abstracts of reports of the international scientific-practical conference "Problems of coordination of military-technical and defense-industrial policy in Ukraine. Prospects for the development of weapons and military equipment", № 7, pp. 158-159 [in Ukrainian].

8. Tomchuk V.V. (2019). Hlobal'ni naukovi ta tekhnolohichni trendy u sferi rozvytku ozbroyennya ta viys'kovoyi tekhniky [Global scientific and technological trends in the field of development of weapons and military equipment]. Abstracts of reports of the international scientific-practical conference "Problems of coordination of militarytechnical and defense-industrial policy in Ukraine. Prospects for the development of weapons and military equipment", № 7, pp. 113-114 [in Ukrainian].

9. Simon Veronneau, Geoffrey Torrington, Jakub P. Hlavka. 3D Printing. Downstream Production Transforming the Supply Chain. RAND Corporation. https://doi.org/10.7249/ PE229

10. Trevor Johnston, Troy D. Smith, J. Luke Irwin. Additive Manufacturing in 2040. Powerful Enabler, Disruptive Threat. RAND Corporation. https://doi.org/10.7249/PE283

11. Bradley Martin, Danielle C. Tarraf, Thomas C. Whitmore. Advancing Autonomous Systems an Analysis of Current and Future Technology for Unmanned Maritime Vehicles. RAND
Corporation. URL: https://doi.org/10.7249/ RR2751

12. Artificial intelligence, strategic stability and nuclear risk: Euro-Atlantic perspectivesnew SIPRI report. SIPRI. URL: https://www.sipri.org/news/2019/artificialintelligence-strategic-stability-and-nuclearrisk-euro-atlantic-perspectives-new-sipri

13. New SIPRI study on autonomy in weapon systems: State of play and options for moving forward. SIPRI. URL: https://www.sipri.org/ media/2017/new-sipri-study-autonomyweapon-systems-state-play-and-optionsmoving-forward

14. Slyusar V. (2017). Batal'yonna taktychna hrupa 2035 roku [Battalion Tactical Group of 2035]. Abstracts of reports of the international scientific-practical conference "Problems of coordination of militarytechnical and defense-industrial policy in Ukraine. Prospects for the development of weapons and military equipment", № 5, pp. 82-83 [in Ukrainian].

15. “Horizon-2020" Program. URL: https://euua.org/horizon-2020

16. Slyusar V. (2019). Poshuk dzherel syly. Problemni aspekty enerhetychnoho menedzhmentu transportnykh platform $-z$ urakhuvannyam osnovnykh trendiv ta pidkhodiv naukovykh struktur NATO [Finding sources of power. Problematic aspects of the energy management of transport platforms taking into account the major trends and approaches of NATO's scientific structures]. Defense Express, № 8, pp. 38-41 [in Ukrainian].

17. Slyusar V. (2019). Vymohy ta tekhnolohiyi dlya vertol'otiv nastupnoho pokolinnya [Requirements and technologies for next generation helicopters]. Proceedings of the International Scientific and Technical Conference "Prospects for the Development of Weapons and Military Equipment of the Land Forces", pp. 262-263 [in Ukrainian].

18. Slyusar V. (2019). Nova systema doslidzhen' i rozrobok sukhoputnykh viys'k USA [A new system of research and development of the US Army]. Weapons and military equipment, № 3 , pp. 123-128 [in Ukrainian]. 
https://doi.org/10.34169/2414-

0651.2019.3(23).123-128

19. Tytti Erästö, Shannon N. Kile and Petr Topychkanov. Nuclear disarmament, arms control and non-proliferation. SIPRI. URL: https://www.sipri.org/yearbook/2019/07

20. Geoffrey Chapman, Hassan Elbahtimy, Susan B. Martin. The Future of Chemical Weapons: Implications from the Syrian Civil War. Security Studies. 2018. № 27. pp. 704-733. https://doi.org/10.1080/09636412.2018.148 3640

21. Caitríona McLeish, Filippa Lentzos. Chemical and biological security threats. SIPRI. URL: https://www.sipri.org/yearbook/2019/08

22. Materials of the NATO Working Group meeting «National Soldier Modernisation Programme» 2018.

23. Richard H. Speier. Hypersonic Missiles: A New Proliferation Challenge. RAND Corporation. URL: https://www.rand.org/ blog/2018/03/hypersonic-missiles-a-newproliferation-challenge.html

24. Christopher Coker. Still "the human thing"? Technology, human agency and the future of war. SAGE. 2018. № 32, pp. 23-38. https://doi.org/10.1177/0047117818754640

25. Sam Kriegman, Douglas Blackiston, Michael Levin, and Josh Bongard. A scalable pipeline for designing reconfigurable organisms. PNAS. 2020. № 117(4). pp. 1853-1859. https://doi.org/10.1073/pnas.1910837117

26. Lillian Ablon, Anika Binnendijk, Quentin E. Hodgson and others. Operationalizing
Cyberspace as a Military Domain. RAND Corporation. https://doi.org/10.7249/PE329

27. Michael J. Mazarr, Ryan Michael Bauer, Abigail Casey and others. The Emerging Risk of Virtual Societal Warfare. RAND Corporation. URL: https://doi.org/10.7249/ RR2714

28. Quentin E. Hodgson, Logan Ma, Krystyna Marcinek, Karen Schwindt. Fighting Shadows in the Dark. RAND Corporation. https://doi.org/10.7249/RR2961

29. William Engdahl F. Gene Editing and "Genetically Modified Humans": China's "Golem Babies". There Is Another Agenda. Global Research. URL: https://www. globalresearch.ca/chinas-golem-babiesanother-agenda/5662154

30. F. William Engdahl. Gene Edited Catastrophe in Brazil. Mosquitos. Global Research. URL: https://www.globalresearch.ca/gene-editedcatastrophe-brazil/5690917

31. Jennifer Conrad. No Man's War: Will Robots Fight the Battles of the Future? Johns Hopkins University Press. 2019. №39(1). pp. 103-106. https://doi.org/10.1353/sais.2019.0009

32. Michel Chossudovsky. Does the US Military "Own the Weather"? "Weaponizing the Weather" as an Instrument of Modern Warfare? Global Research. URL: https://www.globalresearch.ca/does-the-usmilitary-own-the-weather-weaponizing-theweather-as-an-instrument-of-modernwarfare/5608728 